\title{
Enjoying extinction: philanthrocapitalism, jouissance, and 'excessive environmentourism' in the South African rhino poaching crisis
}

\author{
Stasja Koot ${ }^{1}$ \\ Wageningen University, The Netherlands
}

\begin{abstract}
From 2007 till 2015, rhino poaching grew rapidly in and around Kruger National Park, South Africa. And though poaching numbers have declined since then, the 'poaching crisis' and its consequences continue to influence rhetoric and practice in the area, including continuing public outcries that the rhino is close to extinction. This discourse of extinction is also prevalent among the luxurious tourist lodges on private nature reserves of the Greater Kruger Area that attract wealthy tourists. In response, some lodges started initiatives in which tourists can join the fight against rhino poaching. These tourist activities share important similarities with 'philanthrocapitalism', in which wealthy philanthropists address social and environmental challenges drawing on the same business principles that made them successful. Based on research on the tourism industry, I explore the political ecology of such high-end, 'environmentourist' activities. I argue that philanthropic environmental tourist activities are based on a reductionist articulation of the rhino poaching crisis. They de-politicize it from its socio-economic and historical context and are 'excessive', in that they produce and legitimize exorbitant forms of privatized, luxurious tourism and consumerism as a solution for social and environmental crises. Moreover, such 'excessive environmentourism' allows wealthy tourists to enjoy 'doing good' in a very specific way, best captured by the term 'jouissance.' Jouissance is a particular type of ambivalent enjoyment that includes fascination with dark and horrific elements (i.e. poached rhinos and the idea that these animals are at the brink of extinction). I conclude that jouissance functions as a core motivation for wealthy tourists to engage in touristic experiences precisely because it enables them to believe they can overcome the dark sides of their own excesses ironically by 'doing good', grounded in excessive consumption.
\end{abstract}

Keywords: Extinction, enjoyment, jouissance, philanthrocapitalism, South Africa, rhino poaching, tourism

\section{Résumé}

De 2007 à 2015, le braconnage des rhinocéros s'est rapidement développé dans et autour du parc national Kruger, en Afrique du Sud. Et bien que le nombre de braconnage ait diminué depuis lors, la « crise du braconnage » et ses conséquences continuent d'influencer la rhétorique et la pratique dans la région. Le public proteste toujours que le rhinocéros est proche de l'extinction. Ce discours d'extinction est également répandu parmi les lodges touristiques luxueux du Grand Kruger qui attirent des touristes riches, sur des réserves naturelles privées. En réponse, certains lodges ont lancé des initiatives dans lesquelles les touristes peuvent se joindre à la lutte contre le braconnage des rhinocéros. Ces activités touristiques partagent d'importantes similitudes avec le " philanthrocapitalisme », dans lequel de riches philanthropes abordent les défis sociaux et environnementaux en s'appuyant sur les mêmes principes qui ont fait leur succès en affaires. Sur la base de recherches sur l'industrie du tourisme, j'explore l'écologie politique de ces activités «écotouristiques» haut de gamme. Je soutiens que les activités touristiques environnementales philanthropiques sont basées sur une articulation réductionniste de la crise du braconnage des rhinocéros. Ils le dépolitisent de son contexte socioéconomique et historique et sont « excessifs », en ce qu'ils produisent et légitiment des formes exorbitantes de

\footnotetext{
${ }^{1}$ Dr. Stasja Koot, Asistant Professor, Sociology of Development and Change, Wageningen University, The Netherlands; Senior Research Fellow, University of Johannesburg, South Africa. Email: kootwork "at" gmail.com. Acknowledgements: thanks to two reviewers, and the participants at the Crisis Conservation workshop held from 5-9 October 2020. The workshop and the research for this article were made possible by an NWO-VIDI grant (nr. 425-14-001). This is the sixth article in Bram Büscher (ed.). 2021. "Political ecologies of extinction", Special Section of the Journal of Political Ecology 28: 696-888.
} 
tourisme luxueux et privatisé et de consumérisme comme solution aux crises sociales et environnementales. De plus, un tel « écotourisme excessif » permet aux touristes riches de profiter de « faire le bien » d'une manière très spécifique, mieux capturée par le terme « jouissance ». La jouissance est un type particulier de plaisir ambivalent qui inclut la fascination pour les éléments sombres et horribles (c'est-à-dire les rhinocéros braconnés et l'idée que ces animaux sont au bord de l'extinction). Je conclus que la jouissance fonctionne comme une motivation essentielle pour les touristes riches à s'engager dans des expériences touristiques, car elle leur permet de croire qu'ils peuvent surmonter les côtés sombres de leurs propres excès, ironiquement en « faisant le bien ", tout en étant fondés sur une consommation excessive.

Mots-clés: Extinction, jouissance, philanthrocapitalisme, Afrique du Sud, braconnage de rhinocéros, tourisme

\section{Resumen}

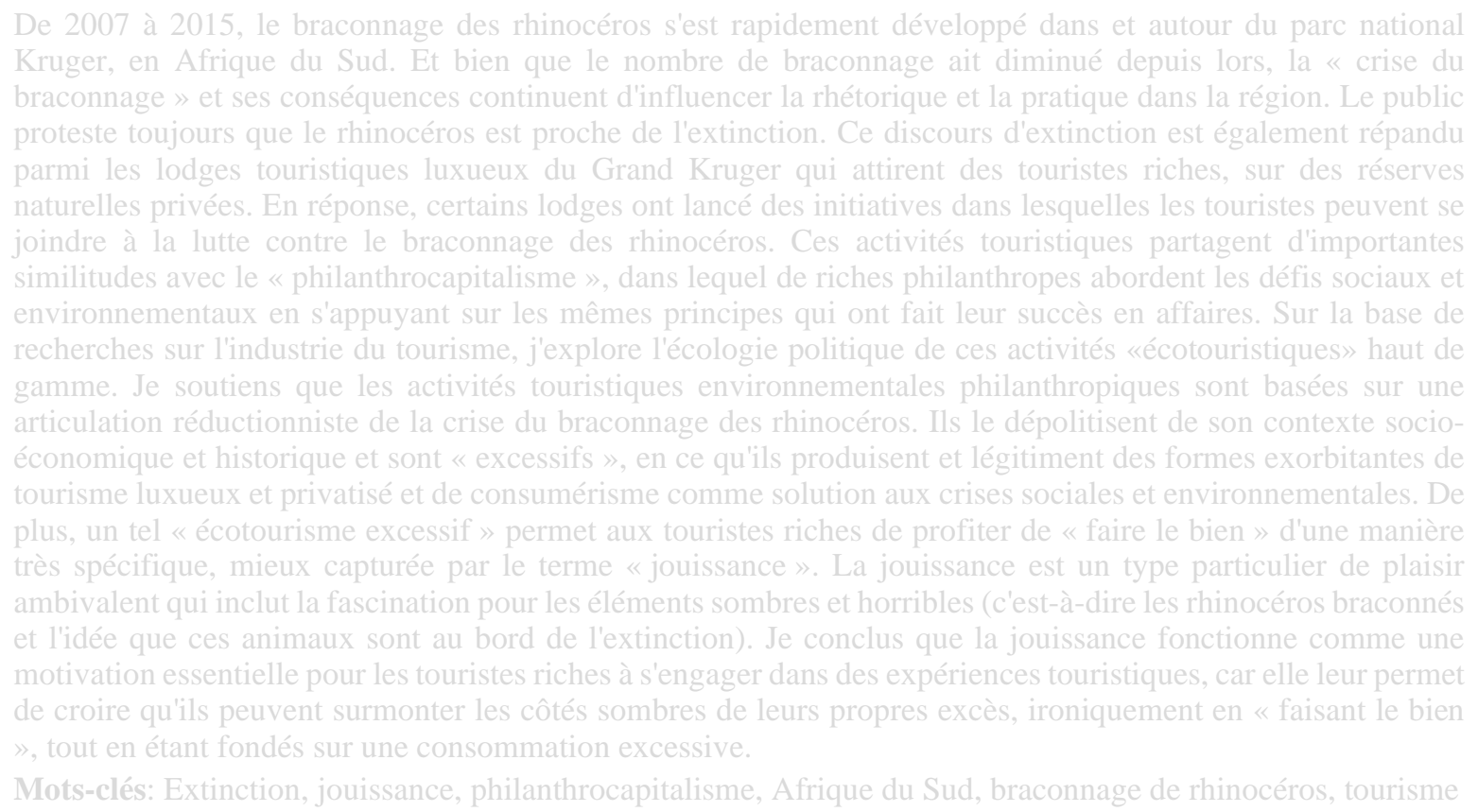

\section{Introduction}

Since 2007, rhino poaching grew rapidly in and around Kruger National Park, South Africa, until 2015, when rhino casualties started to go down again. Many attempts to curb this poaching crisis, and the concomitant, oft-proclaimed extinction of the rhino, have been taken by government, civil society and private actors, including the dehorning of rhinos, 'educating' local communities about nature conservation and, most prominently, the militarizaton of conservation areas (Annecke and Masubelele 2016; Büscher 2016, 2018; Büscher and Ramutsindela 2016; Duffy et al. 2019; Hübschle 2017; Lunstrum 2014, 2016, 2018; Massé and Lunstrum 2016; Morais et al. 2018). Increasingly, the tourism industry has also started to play an important role in curbing the crisis. The connection between the rhino poaching crisis and tourism has, amongst others, been investigated by Massé (2019), whose focus is on the industry's use of social media; Saayman and Saayman (2017), who focus on the species' economic value; Morais et al. (2018), looking at 'community level' tourism micro-entrepreneurship; and Lubbe et al. (2019), who have studied the impact of rhino poaching on the tourism industry and on tourists. I contribute a philanthrocapitalist and psychoanalytic analysis of several anti-poaching initiatives set up by the high-end tourism industry. In most political ecological literature about poaching, sustainable tourism is approached as a market-based income-generating mechanism to provide funds for conservation (see, for example, Brockington, Duffy, and Igoe 2008; Igoe 2017). This reveals important processes of power when people interact with nature, with an emphasis on socio-economic inequality and late capitalist practices (Mostafanezhad et al. 2016). Taking a similar approach, I focus on recent developments in 
the high-end, privatized, or 'excessive' tourism industry, which is excessive in the sense that it promotes elitist lifestyles in which exorbitant material consumption has become the standard: "late capitalist societies (whether in the West or Third World) are characterized by the normalization of excess — the desire for the best, biggest, tallest, richest, most original" (Kapoor 2020: 16).

On the private nature reserves to the west of Kruger — an area referred to as the 'Greater Kruger Area'the already high number of luxury tourist lodges keeps growing (see, e.g., Hoogendoorn, Kelso, and Sinthumule 2019). And many tourists, when they learn about the rhino poaching crisis, "in some way want to be involved in the fight against poaching" (Lubbe et al. 2019: 14). Therefore, the discourse of the rhino as close to extinction has set in motion many philanthropic initiatives to 'save' the species for tourists to provide financial and in-kind support. Subsequently, high-end tourist lodges have now developed a rather large and intriguing suite of activities in which tourists can join the fight against rhino poaching. They can, for example, physically take part in activities to microchip rhinos (and their horns) to track down criminals (KC 2020); visit and donate to a rhino orphanage (RR 2020); do a tour to an anti-poaching unit or visit the world-famous, all-female and unarmed anti-poaching unit the Black Mambas (Pondoro 2017). One activity that stands out is when tourists join a translocation of rhinos to 'safer' havens, where anti-poaching policies are much stricter, such as Botswana.

The article builds on and extends existing literature about philanthropy, capitalism, and conservation, in southern Africa and globally (Diallo 2015; Holmes 2010, 2012; Ramutsindela 2009, 2015; Ramutsindela, Spierenburg, and Wels 2011). Since "the precise means by which philanthropy creates, transforms and mobilizes money, political resources, images and discourses and turns them into conservation practices are unclear" (Holmes 2012: 200), I explore the role of philanthropic tourism activities as an important strategy in this. My analysis of the political ecology of what I call 'environmentourism' provides for a further conceptualization of this niche type of tourism, in which the impact of tourism itself on an environmental problem (in this case rhino extinction) is at the core of the tourism experience (cf. Baptista 2017). This conceptualization is informed by literature about philanthrocapitalism (Bishop and Green 2010; Edwards 2008; Kapoor 2013; Wilson 2014a), in which the wealthy and famous provide support for charities to eradicate poverty and/or to support environmental causes. It refers to philanthropy in which wealthy, successful (and often famous) people claim that the same methods and ideas (business techniques and ways of thinking) that made them successful capitalists should now be replicated to resolve contemporary environmental and social problems (Bishop and Green 2010, see further below).

In addition, the article advances a critique of philanthrocapitalism by uncovering elements of it that take place unconsciously and irrationally (see also Kapoor 2013), especially the 'enjoyment' of philanthropy as created in the interaction between tourists and the industry. Tourism activities provide accessible ways for wealthy tourists to enjoy 'doing good', because, I suggest, the industry sets up these activities in such a way that tourists can find their 'jouissance' in them. ${ }^{2}$ The psychoanalytic concept of jouissance addresses the unconscious and irrational, referring to a particular type of enjoyment that goes beyond 'pure' or conventional ideas about enjoyment: it also includes fascination for the dark and horrific sides of things, such as poached rhinos and the idea that these animals are at the brink of extinction. Furthermore, in environmentourism, the strong focus on exorbitant and excessive consumption is presented as if this creates an ultimate experience of pleasure and relaxation. More critical analyses, however, argue that although holidays tend to be associated with a relief from duties to achieve relaxation, pleasure and a break with obligations, they are also responsible for the exploitation of labor, environmental degradation or cultural destruction (Kingsbury 2005). Tourism's 'just' or conventional enjoyment thus cannot be separated from politically pressing issues of exploitation, domination and environmental degradation (Kingsbury 2005; cf. Žižek 2008).

In what follows, I first present the methodology, followed by an elaboration on environmentourism, philanthrocapitalism, and jouissance, and how they relate. Next, I present several environmentourist initiatives, with a specific emphasis on one particular initiative in which rhinos are translocated from South Africa to Botswana. These activities tap into fantasies of the white savior of African nature, and show how exorbitant

${ }^{2}$ It goes beyond the scope of this article to elaborate on the theoretical embedding of jouissance in psychoanalysis more broadly. See, for instance, Žižek (2008), and for jouissance in relation to tourism, Buda (2015), Fletcher (2014a), Kingsbury (2005) and Koot and Fletcher (2021). For jouissance in relation to philanthrocapitalism see Wilson (2014b). 
luxury goes hand in hand with feelings of disgust and horror about poached rhinos. In the subsequent discussion and conclusion I suggest that within environmentourism the pursuance of jouissance leads wealthy tourists not only to forms of excessive consumption but in fact to see this as their ethical responsibility. In this way, new niche types of ethical tourism come to be seen as sustainable, all the while legitimating the further expansion of neoliberal capitalism as something innately good (cf. Duffy 2015; Fletcher 2011). My final argument is that philanthropic environmentourist activities are based on a reductionist articulation of the rhino poaching crisis, de-politicizing it from its socio-economic and historical context, while legitimizing privatized, luxurious tourism and pushing exorbitant consumerism as a solution for social and environmental crises. Jouissance functions as a core motivation in this for wealthy tourists to engage in touristic experiences precisely because it enables them to believe they can overcome the dark sides of their own excesses ironically by 'doing good' grounded in excessive consumption.

\section{Methodology}

The findings of this article are based on a combination of ethnographic research and critical discourse analysis (CDA). The ethnographic research was focused on tourism in relation to the rhino poaching crisis and the broader 'wildlife economy' on and around private nature reserves in the Greater Kruger Area, South Africa. Fieldwork took place between September 2016 and June 2019 for almost 5 months in total. ${ }^{3}$ During this time, I conducted 87 semi-structured interviews. Interviewees were selected based on their involvement in either the wildlife economy and/or rhino poaching, after which a snowballing method was used by asking for more potential interviewees at the end of interviews. Some 39 interviewees work(ed) in the tourism industry (e.g. lodge owners, managers) and these form the core of the empirical results informing this article. It is important to mention that interviews about rhino poaching and the broader wildlife economy often also provided much information about the tourism industry. Thus, although some of these interviewees did not directly work in tourism, many had much knowledge and a strong opinion about the industry and often worked with the industry (e.g. municipal and provincial government officials, wildlife estate inhabitants, wildlife estate managers and developers, private game reserves' wardens, conservationists). Furthermore, I participated in some of the highend tourism 'anti-poaching' activities, including a visit to a rhino orphanage, a visit to a 'poacher's garden' and an activity organized by a lodge to visit the Black Mamba's all-female anti-poaching unit.

Additionally, CDA was an important methodology (Fairclough 2012; Van Dijk 1993). CDA focuses on "the role of discourse in the (re)production and challenge of dominance [which is] the exercise of social power by elites, institutions or groups, that results in social inequality, including political, cultural, class, ethnic, racial and gender inequality" (Van Dijk 1993: 249-50, emphasis in original). CDA very specifically investigates "what structures, strategies or other properties of text, talk, verbal interaction or communicative events play a role in these modes of reproduction" (Van Dijk 1993: 250; see also Fairclough 2012). Its focus on the (re)production of social power is important in this article; it aligns with an explicit critique on philanthrocapitalism, namely its concentration of power (Edwards 2008; Kapoor 2013), and an analysis of discourse as presented by 'those in power' is therefore an important addition to the ethnographic material. In my selection, I focused on popular and marketing outings (i.e. travel magazines, websites) by the tourism industry about 'do good', or ethical, nature conservation activities they offer for tourists, with a focus on private nature reserves and tourist lodges in the Greater Kruger Area. However, it soon became clear that many linkages were to be found with other areas in, and sometimes outside of, South Africa, due to the often regional and/or (inter)national work of the philanthropic initiatives. I subsequently linked my ethnographic findings to the discourse about rhino poaching, while the industry's articulations of and argumentation for their philanthropic tourist activities gave me the possibility to identify the creation of fantasies and desires on which tourists' jouissance is based. One thread of media sources that is especially important for this article is the 'African Ark' project with actress Uma Thurman and Wilderness Safaris, which was covered by the popular magazine Town \& Country (Glowczewska 2015a). My analysis is based on an interpretation of these qualitative sources. After closely reading many texts and websites, I focused on material about philanthropic initiatives in relation to the South African rhino poaching

3 Over two weeks in September/October 2016, January 2017 and May/June 2019, and approximately one month in July 2017, October/November 2017 and May/June 2018. 
crisis, clearly targeted at high-end tourists, particularly if these initiatives were presented as having a direct impact on the crisis.

\section{Environmentourism, philanthrocapitalism, enjoyment}

\section{Environmentourism}

Tourists travelling to Africa do this mostly from a relatively safe 'tourist bubble', "created to host visitors, the arrangements for their travel, stay, well-being and above all for their safe return home" (Van Beek and Schmidt 2012: 13). This bubble is also prevalent in environmental initiatives for tourists in Africa, that are based on discourses that portray the beauty of African nature as well as its threats, such as extinction. The rhino poaching crisis is loaded with imagery of suffering animals, which are in urgent need of protection (Büscher 2016; Lunstrum 2014), and this protection can now ostensibly be achieved through what I term 'environmentourism.' The neologism 'environmentourism' is inspired by 'developmentourism' (Baptista 2017), in which the focus of the development impact of tourism itself is crucial, since "the merging of development and tourism" into one single practice means the two are not distinct, and thus "should appear as a single word and a single morpheme" (Baptista 2017: 94).

Environmentourism differs from other types of ethical nature-based tourism, including many globally prominent ecotourism initiatives. As a niche type of tourism, environmentourism lacks a core characteristic of ecotourism, namely that 'local communities' are included to be 'developed' and benefit from the tourism activities (see West and Carrier 2004). While ecotourism has a specific focus on sustaining "the well-being of the local people" (TIES 2021), environmentourism only focusses on addressing environmental concerns, and thus ignores local communities' well-being. This does not mean that specific lodges might not also support some type of 'community project' elsewhere, but an environmentourist activity itself is one solely targeting a specific environmental problem. And although environmentourism overlaps with other types of ethical tourism such as volunteer tourism, it still shows important differences: when compared to volunteer tourism, environmentourism has a stronger focus on a nature-based tourist experience infused with wealth and luxury, thereby taking place in an environment of excesses and exorbitance. Furthermore, while it also "creates value in the trade of experiences in or with 'nature"', environmentourism still differs from volunteer tourism because 'voluntourists' are mostly "young people [who] will gain experiences necessary to compete in a highly competitive economy" (Brondo 2015: 1405-1406). Volunteer tourism projects thus target ecological projects that are also opportunities for self-development (Strzelecka et al. 2017). Environmentourism, however, is focused on people who already have become successful in the economy, most of whom are not young anymore.

\section{Philanthrocapitalism}

Environmentourism strongly aligns with some core principles of philanthrocapitalism, in which former types of philanthropy are regarded as largely ineffective, due to their limited integration of basic business principles (Bishop and Green 2010; Farrell 2015). Philanthrocapitalism should be seen as an important element of the contemporary global political economy, in which capitalism adds 'a conscience' to its activities (Farrell 2015). In fact, according to philanthrocapitalist advocates Bishop and Green (2010: 2), "much philanthropy over the centuries has been ineffective. They [philanthrocapitalists] think they can do a better job than their predecessors [by] trying to apply the secrets behind that money-making success to their giving". Important preferences within philanthrocapitalist projects are commercial management styles, short term targets, quantitative goals, and technical solutions for environmental and social challenges (Edwards 2008). Wellknown philanthrocapitalists include Bill Gates, Richard Branson or George Soros, who built up their wealth in the corporate or financial sector, in addition to many celebrities such as Angelina Jolie, Bono or Oprah Winfrey.

Philanthrocapitalism's effectiveness has so far not been proven, and has been heavily critiqued. For instance, it allows for a concentration of power and prosperity among the wealthy. Based on "private visions of the public good" (Raddon 2008: 38), philanthrocapitalist funding is not democratic: decisions are taken by a wealthy elite, and the ideology behind philanthrocapitalism infuses competitive principles into civil society (Dean 2005; Edwards 2008; Giridharadas 2018; Reich 2018). Thus, there is a lack of accountability and political 
legitimacy because "[e]lites decide, according to their own priorities, prejudices, or idiosyncrasies, what causes matter, how much to spend on them, and in what manner" (Kapoor 2013: 65). This ignores attention for structural social changes in the broader political economy (Edwards 2008). Efforts to counter contemporary ecological problems have increasingly been addressed by engaging the same capitalist markets and mechanisms that are for a large part responsible for the same environmental problems (Fletcher 2014b; Büscher et al. 2012). Complex social and environmental issues are presented in a simplified manner, leading to commodification of the problems and presenting markets as 'common sense' (Farrell 2015). Despite these important critiques, philanthrocapitalism's influence is growing, providing a 'business model' that "is sold as a panacea, applicable to government programmes as much as philanthropic causes" (Kapoor 2013: 47).

Philanthrocapitalism becomes increasingly important for political ecology. After all, ecological crises such as the climate and biodiversity crises, are not caused by humans in general, but by the capitalist economic system that aims for endless economic growth while benefiting a minority of wealthy people (Hickel 2020b). In fact, one person among the richest $1 \%$ emits hundred times more $\mathrm{CO}_{2}$ than somebody among the world's poorest half, and the richest $10 \%$ of the global population has emitted more than half of the total $\mathrm{CO}_{2}$ since 1990. Furthermore, rich people tend to invest a lot in ecologically destructive industries (e.g. mining or fossil fuels) to subsequently consume high energy products such as luxury imports, private jets, big cars, business class flights, big houses and excessive holidays (Hickel 2020a). Such behaviour is often aimed at endless material excesses and continually affects the environment and social relations. Furthermore, since philanthrocapitalists are often framed as successful, they set a standard for a much larger culture of excessive consumerism. Thus, although philanthrocapitalism is conventionally associated with the 'very rich', "the essential features of philanthrocapitalism" can today be made available "to everyone" (Bishop and Green 2010: 239). Therefore, it is "not just billionaires and their mega-foundations that command attention" (Reich 2018: 9); seen as a "movement led by these super rich" (Bishop and Green 2010: xi, emphasis added), it is followed by many others (Koot and Fletcher 2020), including wealthy tourists. The pleasure that exorbitant consumption brings about, however, can be regarded more than 'only' conventional pleasure.

\section{Enjoyment/jouissance}

For philanthrocapitalists it is important to be able to enjoy giving away money or 'doing good.' Indeed, "Bill Gates likes to recruit new super-rich philanthropists by telling them how much he is enjoying giving away his money, so fun is part of the popular philanthrocapitalism formula" (Bishop and Green 2010: 244, emphasis added). In addition to addressing global inequality (and environmental problems), Wilson (2014b) explains that philanthrocapitalism, through the mobilization of jouissance, also provides a visceral enjoyment of global inequality. The Lacanian concept of jouissance is not the same as the common-sense understanding of enjoyment: it is "the raw libidinal energy of the bodily drives, which is only experienced as enjoyment when structured by specific fantasies that underpin our sense of reality" (Wilson 2014b: 113). In this case, tourists can tap into fantasies about themselves as white saviors, who are needed to save African nature from brutal, mostly black, poachers (Abidin et al. 2020). Based on colonially grounded, racial inequalities, conservation spaces "create space for white saviors to make their mediagenic interventions" (Abidin et al. 2020: 10; cf. Mbaria and Ogada, 2016). Such fantasies structure our relationship to jouissance, which is simultaneously associated with the pleasure associated with pain, disgust, and the horrified fascination of enjoyment (Wilson 2014a). Furthermore, jouissance contains a continuous expression of excesses (extravagant wealth and luxury) that become normalized, leading to pain and counterproductivity through the seductions of capitalist development "in spite of its production of inequalities and environmental ills" (Kapoor 2020: xiv). These fantasies channel desire for jouissance in specific directions by attaching it to specific objects (i.e. rhinos) that avow to deliver it. This fundamental ambivalence, however, makes jouissance promise gratification it can never really deliver: the pain one experiences in the pursuit of pleasure turns into pleasure in the experience of pain (Žižek, 1989). Thus, fantasy's promise to provide a desired satisfaction in the future conceals the impossibility of this promise and stimulates further pursuance of jouissance.

Through philanthrocapitalism, "[j]ust as we are encouraged to vicariously enjoy the wealth of the philanthrocapitalists, we are equally invited to experience extreme poverty through their eyes" (Wilson 2014b: 
115). To this enjoyment of inequality, I add environmental degradation, which we can experience through the anguish, grief and pain when hearing about climate change or species extinction. By participating in activities to protect the rhino, wealthy tourists buy into this problem as ethical consumers who simultaneously connect to pleasure and pain, including their own anguish and grief about the situation. As a capitalist product, ethical environmental tourism offers experiences of jouissance, creating "a feeling of intense sensation or excitement that, although commonly framed as unequivocal enjoyment, in fact frequently entails significant negative emotions and bodily sensations as well" (Fletcher 2014b: 103). Using the concept of jouissance builds on earlier studies on tourism and hedonism (Malone et al. 2014; Strzelecka et al. 2017), where the pleasure element of (ethical) tourism is central. And although some of these studies have addressed the element of pain too (e.g. Malone et al. 2014), overall the exploration of the attraction that the dark and horror side of contemporary ethical tourism activities can instigate has thus far been limited (Koot and Fletcher 2021). More specifically, no one has investigated how pain and pleasure interact subconsciously and irrationally in tourism, which makes jouissance important when investigating different types of ethical tourism.

I now move to the results section on environmentourism, in which I first position tourism in the Greater Kruger Area in its socio-economic context. Next, I zoom in on the specific case of 'Africa's Ark' and the role of actress Uma Thurman, and how her experience is used as marketing for a specific environmentourist trip. Furthermore, I show the promotion of excessive and exorbitant consumption, in and beyond tourism, and how tourism is presented as the best solution against rhino proaching, while structural inequalities are ignored. After showing that environmentourism is a growing phenomenon well beyond the Greater Kruger Area, I analyze excessive environmentourism in the discussion and conclusion as an extension of philanthrocapitalist ideology that offers jouissance as a core driver of such activities.

\section{Environmentourism against rhinocide?}

Since apartheid was abolished in 1994, disparities in wealth in South Africa have endured, particularly regarding land, which is still largely controlled by a predominantly white minority (Goodman 2017; Koot, Hitchcock, and Gressier 2019). De facto, this is an economic continuation of apartheid for most black people, whose "political liberation has yet to translate into broad material gains" (Goodman 2017; see also Alexander 2002; Bond 2014). An important reason is that private interests have become prioritized, including those of mining, agriculture, and tourism. Communities around the Greater Kruger Area suffer from bad public services, and at times have set up protests on the entrance roads towards Kruger National Park. By closing roads with debris and burning tires, they have prevented international tourists to enter the park, at times throwing stones and intimidating tourists. The protests did not necessarily seek a response from tourists, but by affecting tourism a quicker response is expected from officials. It led a tour operator to explain that the tourists "have to sometimes give up their dream of having one day in the Kruger National Park", while the industry has "become pawns in the non-delivery protests, and I wonder when the police and government are going to act and protect us?" The assumption here is that tourism has nothing to do with the protests. Mainly worried about the industry's image, another tour operator explained that he feared a tourist would get injured, which could "cause a business to crumble" (De Villiers 2018).

Against this background, several interviewees explained they lost trust in the government to address the issue of (rhino) poaching, due to corruption and disinterest. As a lodge owner stated, "I think the private operators, the lodges, are doing far more than the government does" (interview, 15 November 2017). Especially the Sabi Sands private reserve was often presented as a role model, since it "is relatively affluent and can therefore afford higher anti-poaching costs when compared to most other reserves", resulting in much lower poaching numbers. This is regarded as "marketing for our owners, who can explain this to their tourists" (interview, 25 June 2018). However, the protests as described above are part of the broader socio-economic and political context in which contemporary environmentourism thrives. And although it is not my intention here to say that the specific examples in this article are directly related to these activities, or that the industry is to blame for them, I do suggest that the industry plays a crucial role in local and national politics: it needs to legitimize its own presence and influence in the area, and the implementation of environmentourist activities supports this legitimization. 
For many tourism operators, neighboring Botswana is considered a better place for nature conservation. For this reason a lodge and land owner donated an airplane to the government of Botswana to support their antipoaching efforts. Moreover, he is involved in rhino translocations to tourism property in Botswana together with a rich philanthropist from the Netherlands. He explained that the enormous growth of luxurious lodges in the Greater Kruger Area is disturbing:

This growth is not always good from an ecological point of view and it creates much disturbance. For this reason, Botswana is great: at a certain point they have made the choice for top class tourism with high prices so that much money will trickle back into the industry without creating an overload. (interview, 10 November 2017)

However, this high-value/low-volume tourism has received substantial criticism (Magole and Magole 2011; Mbaiwa 2005), including on how at one point it led to a 'shoot-to-kill' policy in protected areas under the Khama administration (Duffy et al. 2019). But this was quickly dismissed by the same lodge and land owner as "very exaggerated [...]. It is not as if the Batswana government are just shooting at everything and everybody there, but if they are being shot at they will shoot back" (interview, 10 November 2017).

Environmentourism's activities are thus not separated from their wider social and political context, and the activities themselves have important consequences for nature and people. I now zoom in onto one project in particular, described as Afrika's Ark in the popular magazine Town \& Country.

\section{"Only tourism can save them"}

The high-end tourism company Wilderness Safaris has long cooperated with the Botswana government, in particular the Botswana Defense Force (BDF), which provides military transport planes and soldiers to assist with rhino translocations. As one of the biggest high-end tourism operators in southern Africa and a selfdeclared "leading conservation and tourism company in the industry today" (WS 2015, emphasis in original), Wilderness Safaris initiated the 'Botswana Rhino Reintroduction Project' in 2001 as a solution against the 'local extinction' of the black rhino in Botswana (WS 2021). The project takes a central position in a magazine article called 'Africa's Ark', marketing this project as a tourist attraction in which tourists can experience "[e]ight adrenaline-fueled days rescuing rhinos in South Africa and Botswana" (Glowczewska 2015a). The popular magazine, Town \& Country, is all about luxury, style, travel and leisure, presenting rhinos as facing extinction due to poaching by 2024 (Glowczewska 2015b), since "wildlife experts estimate they may be gone in just 10 [years]" (Glowczewska 2015a: 159). Furthermore, the urgency to act is emphasized by Wilderness Safaris' CEO explaining that "[w]e have to do this now" (cited in Glowczewska 2015a: 163, emphasis in original). Booking company Explore Inc., which is where this eight-day trip can be booked exclusively, also emphasize the importance to stop "the seeming unstoppable rhino holocaust" (Briggs 2020). To join this fight against extinction, tourists are offered the eight-day rhino relocation trip. Described as a "safari like no other", this trip provides tourists "[a]n unprecedented opportunity to participate in the most dramatic conservation story of the $21^{\text {st }}$ Century" (Glowczewska 2015b). The magazine article (Glowczewska 2015a) and the description of the trip on the Town \& Country website (Glowczewska 2015b) are both focused on potential high-end tourists, attempting to lure them into the Botswana Rhino Reintroduction Project. Dramatic narratives about helpless rhinos, their expected extinction and ruthless poachers are easily alternated with descriptions of the safari as luxurious and exorbitant, and how one can be part of the solution. This way, pleasure and pain are continually used as bait for potential tourists who can buy into the fantasy of saving Africa's threatened nature.

The trip starts off with a charter flight from Johannesburg to the Royal Malewane safari lodge at the Thornybush Private Nature Reserve in the Greater Kruger Area, which is "as opulent as safari lodges get [and where you can b]eat your jetlag with a massage or a swim at the spa" (Glowczewska 2015b). The lodge is a proud founding member of the Greater Kruger Environmental Protection Foundation (GKEPF), a military antipoaching initiative that would not "be possible without the valuable patronage of our guests, many of whom generously contribute additional funds after coming face to face with these majestic creatures [rhinos] at Royal Malewane" (RM 2020). By doing this, guests thus also support the increase of militarized interventions to 
prevent poaching. During the first three days at Royal Malewane, tourists receive an introduction to nature conservation, they do several game drives, a walking safari, sundowners and star constellation watching. On day four, they fly to Johannesburg and stay there for one night. In the afternoon and evening they can consider any type of 'urban' activity, to continue the journey to Botswana the next morning. Alternatively, tourists can choose to book a charter from Royal Malewane (at additional cost) straight to Wilderness's Mombo Camp in the Moremi Game Reserve, Botswana (Glowczewska 2015b). Just like Royal Malewane, Mombo Camp "is luxury au naturel: canvas tented suites on raised wooden walkways, indoor and outdoor showers, 100 percent solar-powered (Wilderness Safaris walks the sustainability talk), with private and public bars, generously stocked" (Glowczewska 2015a: 172). Here the tourists stay for the last three days. On arrival, tourists receive a briefing during high tea on how Wilderness Safaris supports rescuing rhinos; they can experience a (relocated) rhino capture from a helicopter; they can monitor their whereabouts and health; they can fit the animals with tracking devices; if lucky, they can even witness the release of a rhino back into the wild. Furthermore, because it is "largely Botswana's diamond wealth that enables its exemplary conservation stance" (Glowczewska 2015b), it is also possible to visit a diamond mine run by the world's second-largest diamond company DeBeers. The trip is expensive: US\$ 18,655 per person and a tax-deductible requirement of US\$ 25,000 per person for the Wilderness Wildlife Trust to Rhino Conservation Botswana (Glowczewska 2015b; see also WWT 2016).

Importantly, the project was supported by Botswana's former President Ian Khama and his brother the Minister of Environment, Wildlife and Tourism, Tshekedi 'T.K.' Khama. While the protection of natural resources in Botswana used to be the main mission of the BDF (Glowczewska 2015a), former president Khama is one of the shareholders of Linyanti Investments, a subsidiary of Wilderness Holdings, and his nephew and lawyer are also on the board of Wilderness Holdings (Ntibinyane 2011). This could explain why Wilderness Safaris is Botswana's "longtime partner" (Glowczewska 2015a: 161), in the country where T.K. Khama proudly articulated the urgency to shoot potential poachers if "they do not surrender their arms immediately on request" (Glowczewska 2015a: 201).

Political and economic elites were complemented by further including Hollywood actress Uma Thurman. In the Town \& Country article, the eight-day trip is promoted with 'tough girl' Thurman as 'the tourist.' Her support is meant to attract "passionate travelers with a deep interest in conservation", whose trip "will closely parallel Uma's adventure" (Briggs 2020). She agreed to support the prevention of what she dubbed "rhinocide", which refers to the pain one feels when experiencing (stories about) the slaughter of rhinos (Glowczewska 2015a: 161). In classic jouissance terms, Thurman explained that "[t]he beauty of these animals and the absurdity of their plight is so painful" (in Glowczewska 2015a: 161). This pain showed in a promotional video, together with her happiness, when she cried at the release of rhinos at the end of her trip (T\&C 2015). In the extensive article, many moments of pleasure and pain are described to further promote this type of environmentourism focused on philanthropic engagement and funding (Glowczewska 2015a,b). For instance, in addition to the strongly articulated focus on consuming tourism experiences to support the quest against rhino extinction, excessive consumption is promoted more generally throughout the Africa's Ark article: Thurman also functions as a model on pictures throughout the article, branding luxury clothes and jewelry with their prices, including Purdey, Ralph Lauren, Rolex and Chopard (Glowczewska 2015a). This shows the opulent character of the high-end tourism industry, related media and private nature reserves, creating an "enclosed condition of elite life that appeals to fantasy, sometimes eccentricity, but defines immersion in an environment that sets a limit on and horizon of experience" (Marcus 2018: 63).

As Thurman reflected back on the trip, she concluded: "[t]here is always hope" (Glowczewska 2015a: 202). The eight-day trip, or environmentourism more generally, is an important exponent of this hope: it promises tourists that they can be an important part of the solution, easing the pain of poaching by joining pleasant tourist experiences, all the time embedded in exorbitant luxury. Wilderness' CEO, for instance, explains that the tourists are crucial for them to be able to raise all the funds. This apparently shows

...how crucial all tourism in Africa is to the survival of wildlife and the wilderness. If travelers don't come to safari lodges, human population pressure is such that over time the land on which animals now roam will be repurposed-for cattle, agriculture, or development. African 
communities will lose the jobs tourism generates (Mombo Camp employs 2.5 people for every bed), and the only places you'll be able to see a rhino or hear a lion roar will be in a zoo. (Glowczewska 2015c)

The owner of Explore Inc. added that "this is what 'tourism' is all about—conserving the last havens for wildlife in our fantastic natural world. African wildlife is under siege [and o]nly tourism can save them" (Briggs 2020, emphasis added).

\section{The tourism solution in context}

This core idea-that tourism is crucial to solve rhino poaching-is widely shared among lodge owners and managers in the Greater Kruger Area. One lodge owner and investor in several reserves explains:

I am often blamed for my high prices. [...] We as landowners are forced-and we do this with love-to invest a lot of money in protecting these animals, but one way or the other it needs to be paid for. If you as tourists do not want to pay for it, then there won't be any rhinos anymore. [...] The tourist also has a big responsibility here: a tourist must be willing to pay for this otherwise there will be no protection. (interview, 10 November 2017)

Spectacles of consumption, presented as a 'responsibility', are targeted at wealthy people, forsaking in-depth analysis of broader socio-economic structural problems relating to the rhino poaching crisis. This includes often deplorable labor circumstances at the private nature reserves and in conservation, often failing public services and racial and socio-economic inequalities, and land ownership injustices that have historically been created under colonialism and apartheid (Ramutsindela 2015; Hübschle 2017; Morais et al. 2018; Thakholi 2021). One could argue that such structural inequalities are crucial causes of poaching, but that does not withhold some people to regard 'the rich' philanthropists as the saviors, as this manager of a collection of luxury lodges explained:

I have this very interesting theory about rhinos and private reserves: Do rhinos belong to the poor or they belong to the rich? It belongs to the rich! All the land, game farmers and all these estates are private reserves. It's rich and super-rich. I am not talking about middle-class; I am talking about rich. My theory is: why should the public come and fund your anti-poaching? I always believe if you buy the Range Rover but you cannot afford the fuel, don't have it. If you cannot afford to look after your rhinos, then you sell it. At Thornybush [where Royal Malewani is situated] we don't have any funds for anti-poaching, it is all funded by the reserve, and [...] at Thornybush, or Timbavati, or Sabi Sands, you know, there is all billionaires. (interview, 15 November 2017)

Nonetheless, some lodge owners are very critical about 'selling' environmentourism as 'philanthropic', as the following lodge owner and rhino breeder explains:

My estimate is that we spend about [ZAR] 150,000 to 250,000 per rhino a year. ${ }^{4}$ At Sabi Sands [...] I tell my neighbors 'we are not doing conservation', it's for commercial reasons, we want to show it to our guests. Once we have made that honest decision, we can respond accordingly. If we were doing conservation by saving a species from the brink of extinction, which we are not, then you cannot shoot people. If you are doing it for commercial imperative, then you can't shoot people. [...] I do not believe that the rhino are remotely on the brink of extinction in South Africa. (interview, 24 July 2017)

\footnotetext{
${ }^{4}$ About US\$ 11.575,- to 19.291,- at the time, based on https://www.wisselkoers.nl/calculator.
} 
Following this line, Ramutsindela (2015: 2260) calls this type of environmental philanthropy "extractive", meaning that it achieves three interrelated objectives, namely "to push back land claims, to give wealth-generating activities a human face, and to control a labour pool for purposes of upmarket ecotourism ventures". However, an owner of various lodges in the area, who is himself involved in several philanthropic endeavors, does not consider the large-scale land privatizations (that are essentially in conflict with a variety of land claims) as problematic:

Privatization is not a problem; Kruger park is public and provides access to larger groups of people. It is even necessary because due to private investments about 250,000 hectares to 300,000 hectares have been added to the park. This has been very important for the numbers of wildlife and the ecology. (interview, 10 November 2017)

Nature is thus often prioritized, and environmentourist activities disentangle it from socio-economic structures, especially inequality, and disregard problematic histories. By doing this, environmentourism legitimizes the existence of high-end privatized tourism, its excessive consumerist lifestyles and the land it needs. This gives the capitalist activities an 'ethical' twist and a 'conscience' (cf. Farrell 2015). Such legitimization also shows when lodge owners explain to collaborate with communities, for example by setting up community tourism camps (that operate separately from the luxurious lodges) to provide local people with jobs. One lodge owner explained:

The industry now tries to involve the communal areas, often areas that are not being used, or being used faulty, in such a way that it does not create any benefits. So the traditional use of land for small-scale agriculture is very inefficient from an economical point of view. (interview, 10 November 2017)

Well-intended philanthropic community tourism projects consequently were set up based on the classic philanthrocapitalist idea that "the only way to make this a success is to run it as a proper business" (interview, 10 November 2017). However, one lodge manager emphasised that community tourism and the jobs that tourism generates more generally are very limited, and that structural issues are more demanding:

Some of my lodges, I would say, you pay maybe [ZAR] 20,000 per room per night, other lodges is 30,000 per person per night, ${ }^{5}$ there around. There is going to come a level when staff and the community are going to question: what is happening with that money? Are we making the rich richer? How much of that money is filtered back in the communities? [...] You can't have this disparity between very poor people and extremely rich people literally a mile apart. (interview, 15 November 2017)

And in the highly competitive Greater Kruger Area with a growing number of high-end lodges, it becomes increasingly important to show your 'uniqueness.' Simply more luxury is not enough anymore and although it remains attractive, it clearly has its limits. The horror of an extinction crisis, however, can reinvigorate a unique tourism possibility, creating excitement and fulfilling one's search for meaning. As explained by an interviewee:

It's [...] good selling, you know, we've got a K9 unit [military or police trained sniffing dogs] and we've got 14 anti-poachers, it sells well, you know, 'cause you need to differentiate these days, you know, all these different lodges we do all the same, we do game drives, we've got a smart room, you get a steak, a massage and a pool, but you always want to do something different. (interview, 15 November 2017)

\footnotetext{
${ }^{5}$ About US\$ 1,387 and US\$ 2,079 respectively at the time, based on https://www.wisselkoers.nl/calculator.
} 
Environmentourism activities can fill this lack by tapping into the fascination that potential tourists have about the 'repulsive' poaching crisis, thereby increasing lodges' market value. Furthermore, they bring together political and economic elites, including wealthy tourists, and are grounded in fantasies about rhinos in need of saving from 'bad' poachers. The discourse continually alternates between the pleasure (luxury, comfort, but most of all the fantasy about oneself as an important savior of African nature) one derives from fighting the horror of poaching, allowing tourists to experience jouissance.

\section{Environmentourism beyond the Greater Kruger Area}

The examples above are not isolated ones. For instance, the two luxury tourism companies \&Beyond Phinda Private Game Reserve and Great Plains Conservation collaborate in a project called 'Rhinos Without Borders', an initiative that "calls on all members of the travel industry to join hands in order to make a difference" (RWB 2016) to be able to translocate rhinos from private game reserves in South Africa to Botswana. Similar to Wilderness Safaris, this project also presents the rhino as nearly extinct, offering tourists a "fundraising safari", to support the translocation of 100 rhino "from South Africa to safe havens in Botswana" (AfricaDiscovery 2014), which, according to the Great Plains CEO, "has an excellent security system in place" that will support the survival of the species "for future generations to enjoy" (AfricaDiscovery 2014). ${ }^{6}$ In fact, "both Great Plains Conservation and \&Beyond will announce specific fundraising initiatives to enable tourism stakeholders, travel partners, tour operators and guests to help save this iconic species" (AfricaDiscovery 2014). In this case, an eleven-day safari costs 'only' US\$13,200 per person, including a donation for Rhinos Without Borders, but if a tourist is willing to donate between US\$250,000 and US\$ 1 million he/she also receives a nine-day safari for two people (Lunstrum 2018). Additionally, there are possibilities to book a 'rhino conservation experience' (including de-horning and rhino notching/tagging), a 'rhino notching experience' or a three or four-day 'rhino conservation safari' (including darting and notching) (RWB 2020). Just like Uma Thurman, both the CEOs of \&Beyond and Great Plains Conservation felt tears welling up when watching translocation activities (see McNicoll 2018), tears that are likely a result of pleasure because one has actively reduced the 'pain of poaching.'

Such environmentourism is not limited to southern Africa or the rhino. \&Beyond, for instance, has now started "more interactive itineraries such as the Phinda Impact Small Group Journey and the Oceans Without Borders Small Group Journey or our Travel With Purpose tours in South Africa and East Africa" (McNicoll 2018). Some safari lodges offer the opportunity to tourists to fit elephants with GPS collars to reduce humanwildlife conflict in Tanzania. Promoted as "safaris with a purpose", tourists can enjoy a four nights/five days full board safari, including game drives, all meals and beverages, gin, archery, wine tastings and tennis from "USD 19,464 for 4 people plus a tax deductible contribution of USD 25,000 per person" for the collaring project (Singita 2020). Moreover, tourists can also experience exposure to "high tech anti-poaching headquarters, training with the new canine unit, learning more about the Environmental Education Centre and other community outreach projects", all the while enjoying luxurious accommodation facilities (Singita 2018). Collaborations with communities, however, should, according to the CEO of \&Beyond, be done with community development committees that are "as apolitical as possible" (McNicoll 2018, emphasis added). Altogether, this confirms findings in critical literature regarding the continued marginalization of surrounding communities and the de-politicization and de-historicization of structural causes of the rhino poaching crisis and conservation more generally (Hübschle 2017; Ramutsindela 2015; Thakholi 2021). Moreover, it disregards problematic aspects of neo-colonial, racial and ethnic power inequalities within the South African tourism industry (Koot 2016; Morais et al. 2018). De-politicization, in this context, refers to "the removal of public scrutiny and debate, with the result that issues of social justice are transformed into technocratic matters to be resolved by managers, 'experts', or [...] celebrities" (Kapoor 2013: 3). Environmentourism thus provides for

\footnotetext{
${ }^{6}$ In 2020, after tourism had reduced tremendously due to the COVID-19 pandemic, the number of poaching incidents were rising in Botswana. The Great Plains CEO blames this on the absence of safari tourists and subsequent reduced human presence. As a result, in April 2020, "six poachers were killed by law enforcement", and the government of Botswana intensified its anti-poaching surveillance. Ironically, wildlife officials and Rhinos Without Borders are now collaborating to evacuate the rhinos again to a confidential location elsewhere in Botswana (Maron 2020).
} 
unique, de-politicized and de-historicized consumption experiences, in which pleasure and pain continually interact. I now move to the discussion and conclusion of these findings in relation to philanthrocapitalism and jouissance.

\section{Discussion and conclusion: enjoyment in the environmentourism bubble}

Environmental problems such as rhino poaching are often presented in a reductionist and simplified manner, disregarding the important social, political economic and historical contexts of such problems that are the focus of political ecology (Biersack 2006). The high-end tourism industry is no exception to this, and thus its activities are relevant to the field of political ecology more generally: they need to be seen within their broader context, and the relatively powerful position of the high-end tourism industry continually mediates human-environment relations. This emphasises the importance of environmentourism for political ecology, as a niche in nature-based tourism, which contains two core characteristics. First, the tourism itself impacts a specific environmental problem, and second, this happens in an elitist environment. Regarding the latter, Hübschle (2017: 440) explained that current conservation initiatives are often based on

...archaic and elitist preservation and conservation paradigms that discount the potential for harmonious relationships of local communities and wildlife. In the modern context, protected areas continue to present manifestations of colonial dispossession, apartheid segregation and neoliberal expansion. Conservation areas are seen as symbols of elite interests and wealth, inaccessible to the poor majority.

Subsequently, the problem, i.e. the rhino poaching crisis in this article, is commodified through the presentation of solutions, dressed-up as tourism spectacles, that people can take part in. However, the translocation of rhinos to 'safer haven' Botswana indeed used to be safer for rhinos due to a shoot-to-kill policy directed at people. Moreover, the Botswana style of tourism, which is focused on the promotion of high-end luxurious tourism, is in this case considered the solution against extinction, despite the creation of 'enclave tourism', the removal of profits from Botswana, the ownership of many tour operators by foreigners, and separating large parts of the rural population from natural resources (Magole and Magole 2011; Mbaiwa 2005). Nonetheless, this type of tourism is what many reserve and lodge owners envisage in the Greater Kruger Area: "a type of ecotourism that supports the conservation of the environment by minimizing the ecological impact of tourists" (Ramutsindela 2015: 2263). In line with philanthrocapitalist ideology, many people stated a broad distrust in the (South African) government, and especially interviewees from the private tourism sector articulate a similar suspicion for the many NGOs also undertaking initiatives to protect the rhino or to invest in community development, which they generally believe they can do much better.

Excessive environmentourism in the Greater Kruger Area has thus become an important form of 'ethical consumption', based on self-congratulatory rhetoric about its beneficial outcomes while obscuring environmental and social consequences (Fletcher 2014b). In fact, it goes even further when industry representatives say that wealthy tourists are responsible for saving the rhino through consumption, so that without doing their 'duty' by enjoying this crisis, the rhino would go extinct. In this process, conservationists "may frame biodiversity issues in ways which facilitate philanthropy, by positioning them as merely needing philanthropy, rather than more structural political and economic changes, to be resolved" (Holmes 2012: 190). This opens up avenues within philanthrocapitalist ideologies for many others to 'buy ethically', ensuring that "consumers are induced to become de facto philanthropists" (Kapoor 2013: 66), boosting corporations' brands and giving them legitimacy. The urgency of the rhino poaching crisis creates an anti-intellectual attitude that urges people not to think, but to do, unquestioningly accepting the status quo. In environmentourism then, it is important that the performance of the act is visible, much more than the content of the act (cf. Debord 1967).

The presentation of Uma Thurman as a mover of nature conservation shows how celebrities play a crucial role in reproducing elite social networks (Brockington 2009). They create opportunities for 'everyday people' to mimic the powerful and famous (Igoe 2017). Kapoor (2013), in relation to humanitarianism, argues that celebrities play an important role in the legitimization and promotion of global inequality and neoliberal 
capitalism, from which they continually benefit. Typical of philanthrocapitalism is that celebrities and their charity work function as a promotion of capitalism as the solution to contemporary social and environmental problems, leaving the governing elites mostly unaccountable for their role in larger structural environmental and social issues (cf. Kapoor 2013). The philanthrocapitalist environmentourists in this case become "the audience, $[\ldots]$ integral to, and complicit in, the process - through our fandom, our enjoyment of the celebrity spectacle, our consumption of charity products" (Kapoor 2013: 3-4). An important driver in this process is, of course, jouissance.

\section{The role of jouissance}

From a dominant position, tourists experience jouissance: capitalism provides them with glamorous lives, in which they can enjoy capitalism to the fullest and promote it. At the same time, their position as the dominant saviors also provides for the secret enjoyment of the pain that capitalism inflicts on many other people and the environment, creating pleasure for those in charge (cf. Kapoor 2013). Jouissance thus plays an important role in this when responding to the urgent call to save the rhino from the brink of extinction, as articulated by many industry actors today.

Our fantasies and desires are continually exploited under capitalism, offering new products for consumption that can never truly satisfy and thereby create a continuous (feeling of) absence. Consumption and materialism address this absence and keep capitalism going (Fletcher 2018). Because people feel "that what they have is inadequate. It creates constant pressure for people to learn and buy more - not because they actually need it, but because they want to approximate the consumption habits of richer people" (Hickel 2020a). However, this leads to us "buying more stuff in order to feel better about ourselves, but it doesn't work because the benchmark is perpetually out of reach" (Hickel 2020a). Absence is continually confirmed and activated through advertisements articulating mimetic enjoyment. Thurman's modelling for luxurious brands, aimed at wealthy tourists inspired by the African Ark story, shows how "the excess of the powerful and wealthy itself serves as advertisement, spurring mimetic consumption by those at the middle and bottom of the social ladder" (Kapoor 2020: 104). Most of the burden of an exorbitant lifestyle is put on marginalized groups around the world, e.g. through the climate crisis or abhorrent labor circumstances in sweat shops. Emotional and commodified encounters with animals might "reshape societal relations with nature, but [do so] in uneven and incomplete ways" (Duffy 2015: 529). Environmentourism thus intensifies and expands global structures of inequality and exploitation under neoliberal capitalism. Jouissance then also becomes a distributor of pleasure and pain; it directs one pain (e.g. the pain one feels when watching a poached rhino) onto others (e.g. marginalized people).

Today, the tourism industry has become "a large scale industry that sells solutions to both local social problems in the Global South and existential ethical crisis in 'the North"' (Baptista 2017: 17). By choosing a particular form of tourism, tourists affirm "their personal and socio-cultural identity" (Salazar 2004: 85). It is important that such experiences are branded as unique; they need to be authentic for the tourists and have an impact on them in various ways, including self-realization and the search for identity through consuming ethical activities (Salazar 2004). In fact, "[t]oday such imagined possibilities, opportunities to participate in philanthropic activities, are often part of the appeal of nature experiences that tourists choose between" (Igoe 2017: 30). The safe African tourist bubble created for the consumption and commodification of nature provides environmentourists with a platform on which they can have such 'authentic' experiences of doing good, a means to address their fantasies through creations in the tourism industry. In excessive environmentourism, the tourist bubble has become much more than simply a safe haven, it is mostly an environment "that elites create for themselves [...] they can feel immersed in an opaque or translucent bubble [depending on] a limit on looking in their surrounds that only confirms a particular reality" (Marcus 2018: 63-64). Tourism in these areas provides for a real, physical fence, as well as a psychological space within which one can save the world without (fully) taking part in it through evermore excessive consumption.

This article has shown how the industry provides for such environmentourist experiences through a continuous pursuit of jouissance, but it does not present any tourist perspectives. Such perspectives and the meanings attached to environmentourist experiences still need further exploration, not only in 
environmentourism but broader in 'do good' or ethical tourism (Koot and Fletcher 2021; Malone et al. 2014). In the end, the pleasure that such types of tourism instigate cannot—and thus should not-be seen apart from its connection with pain, horror and disgust. The larger consequence of the 'sustainability' of such ethical tourism is, however, the expansion of neoliberal capitalism, confirming capitalism's innate 'goodness' and its consequent further progress (cf. Duffy 2015; Fletcher 2011). This generally happens without acknowledging tourism's role in socio-economic, racial and environmental problems. Overall, this leads me to argue that philanthropic environmentourist activities are based on a reductionist articulation of the rhino poaching crisis, de-politicizing it from its socio-economic and historical context, while legitimizing privatized, luxurious tourism and pushing exorbitant consumerism as a solution for social and environmental crises. Jouissance functions as a core motivation in this: wealthy tourists engage in touristic experiences precisely because it enables them to believe they can overcome the dark sides of their own excesses, ironically by 'doing good' while grounded in excessive consumption.

\section{Bibliography}

Abidin, C., D. Brockington, M. Goodman, M. Mostafanezhad and L. Richey. 2020. The tropes of celebrity environmentalism. Annual Review of Environment and Resources 45(1): 387-410.

AfricaDiscovery. 2014. andBeyond and Great Plains join forces to translocate up to 100 rhino. [accessed 2 October 2018]. https://www.africa-discovery.com/blog/?p=265.

Alexander, N. 2002. An ordinary country: issues in the transition from apartheid to democracy in South Africa. Scottsville: University of Natal Press.

Annecke, W., and M. Masubelele. 2016. A review of the impact of militarisation: the case of rhino poaching in Kruger National Park, South Africa. Conservation and Society 14: 195-204. http://doi.org/10.4103/0972-4923.191158

Baptista, J. 2017. The good holiday: development, tourism and the politics of benevolence in Mozambique. New York: Berghahn.

Biersack, A. 2006. Reimagining political ecology: culture/power/history/nature. In Biersack, A. and J. Greenberg (eds.). Reimagining political ecology. North Carolina: Duke University Press.

Bishop, M. and M. Green. 2010. Philanthrocapitalism: how giving can save the world. London: A \& C Black.

Bond, P. 2014 [2000]. Elite transition: From apartheid to neoliberalism in South Africa (revised and expanded Edition). London: Pluto. First edition

Briggs, C. 2020. Rhino Rescue with Uma Thurman. [accessed 26 February 2020]. https://www.exploreinc.com/rhino-rescue-with-uma-thurman/.

Brockington, D. 2009. Celebrity and the environment: fame, wealth, and power in conservation. London: Zed.

Brockington, D., R. Duffy and J. Igoe. 2008. Nature unbound: conservation, capitalism and the future of protected areas. London: Earthscan.

Brondo, K. 2015. The spectacle of saving: Conservation voluntourism and the new neoliberal economy on Utila, Honduras. Journal of Sustainable Tourism 23(10): 1405-1425.

Buda, M. 2015. The death drive in tourism studies. Annals of Tourism Research 50: 39-51.

Büscher, B. 2016. "Rhino poaching is out of control!" Violence, race and the politics of hysteria in online conservation. Environment and Planning A 48(5): 979-998.

Büscher, B. 2018. From biopower to ontopower? Violent responses to wildlife crime and the new geographies of conservation. Conservation and Society 16(2): 157-169. http://doi.org/10.4103/cs.cs_16_159

Büscher, B. and M. Ramutsindela. 2016. Green violence: Rhino poaching and the war to save Southern Africa's Peace Parks. African Affairs 115(458): 1-22.

Büscher, B., S. Sullivan, K. Neves, J. Igoe and D. Brockington. 2012. Towards a synthesized critique of neoliberal biodiversity conservation. Capitalism Nature Socialism 23(2): 4-30.

De Villiers, S. 2018. Protests around Kruger National Park leaves grim footprint. Lowvelder, 29 March. 
Dean, J. 2005. Communicative capitalism: circulation and the foreclosure of politics. Cultural Politics 1(1): 5174.

Debord, G. 1967. Society of the spectacle. Detroit: Black \& Red.

Diallo, R. 2015. Conservation philanthropy and the shadow of state power in Gorongosa National Park, Mozambique. Conservation and Society 13(2): 119-128. http://doi.org/10.4103/0972-4923.164188

Duffy, R. 2015. Nature-based tourism and neoliberalism: concealing contradictions. Tourism Geographies 17(4): 529-543.

Duffy, R., F. Massé, E. Smidt, E. Marijnen, B. Büscher, J. Verweijen, M. Ramutsindela, T. Simlai, L. Joanny, and E. Lunstrum. 2019. Why we must question the militarisation of conservation. Biological Conservation 232: 66-73.

Edwards, M. 2008. Just another emperor? The myths and realities of philanthrocapitalism. New York: Dēmos.

Fairclough, N. 2012. Critical discourse analysis. International Advances in Engineering and Technology 7: 452-487.

Farrell, N. 2015. 'Conscience capitalism' and the neoliberalisation of the non-profit sector. New Political Economy 20(2): 254-272.

Fletcher, R. 2011. Sustaining tourism, sustaining capitalism? The tourism industry's role in global capitalist expansion. Tourism Geographies 13(3): 443-461.

Fletcher, R. 2014a. Romancing the wild: cultural dimensions of ecotourism. North Carolina: Duke University Press.

Fletcher, R. 2014b. Taking the chocolate laxative: why neoliberal conservation "fails forward". In Büscher, B., W.H. Dressler and R. Fletcher (eds.). Nature ${ }^{\mathrm{TM}}$ inc.: environmental conservation in the neoliberal age. Tucson: University of Arizona Press.

Fletcher, R. 2018. Beyond the end of the world: breaking attachment to a dying planet. In Kapoor, I. (ed.). Psychoanalysis and the global. London: University of Nebraska Press.

Giridharadas, A. 2018. Winners take all: the elite charade of changing the world. New York: Borzoi.

Glowczewska, K. 2015a. Africa's Ark. Town \& Country, October: 158-202.

Glowczewska, K. 2015b. Eight adrenaline-fueled days rescuing rhinos in South Africa and Botswana. [accessed 5 May 2021]. https://www.townandcountrymag.com/leisure/travel-guide/a3689/rhino-rescue-trip/.

Glowczewska, K. 2015c. Uma Thurman's journey to protect Africa's wildlife from vicious poachers. Town \& Country, reprinted Des Moines Register, Ocotber [accessed 5 March 2020]. https://eu.desmoinesregister.com/story/news/features/2015/09/10/uma-thurmans-journey-to-protectafricas-wildlife-from-vicious-poachers/72007168/.

Goodman, P. 2017. End of apartheid in South Africa? Not in economic terms. The New York Times, 24 October. Hickel, J. 2020a. We can't have billionaires and stop climate change. The Correspondent, 9 October.

Hickel, J. 2020b. What does degrowth mean? A few points of clarification. Globalizations https://doi.org/10.1080/14747731.2020.1812222

Holmes, G. 2010. The rich, the powerful and the endangered: conservation elites, networks and the Dominican Republic. Antipode 3: 624-646.

Holmes, G. 2012. Biodiversity for billionaires: capitalism, conservation and the role of philanthropy in saving/selling nature. Development and Change 43(1): 185-203.

Hoogendoorn, G., C. Kelso and I. Sinthumule. 2019. Tourism in the Great Limpopo Transfrontier Park: a review. African Journal of Hospitality, Tourism and Leisure 8(5): 1-15.

Hübschle, A. 2017. The social economy of rhino poaching: of economic freedom fighters, professional hunters and marginalized local people. Current Sociology 65(3): 427-447. doi: 10.1177/0011392116673210.

Igoe, J. 2017. The nature of spectacle: on images, money, and conserving capitalism. Tucson: University of Arizona Press.

Kapoor, I. 2013. Celebrity humanitarianism: the ideology of global charity. London: Routledge. 
Kapoor, I. 2020. Confronting desire: psychoanalysis and international development. Ithica: Cornell University Press.

KC. 2020. Kings Camp: Rhino chipping experience. [accessed 21 February 2020]. https://www.kingscamp.com/rates-offers/rhino-chipping-experience/.

Kingsbury, P. 2005. Jamaican tourism and the politics of enjoyment. Geoforum 36: 113-132. doi: 10.1016/j.geoforum.2004.03.012.

Koot, S. 2016. Contradictions of capitalism in the Kalahari: indigenous Bushmen, their brand and baasskap in tourism. Journal of Sustainable Tourism 28(8\&9): 1211-1226. https://doi.org/10.1080/09669582.2016.1158825

Koot, S. and R. Fletcher. 2020. Popular philanthrocapitalism? The potential and pitfalls of online empowerment in "free" nature 2.0 initiatives. Environmental Communication 14(3): 287-299. https://doi.org/10.1080/17524032.2019.1649707

Koot, S. and R. Fletcher. 2021. Donors on tour: philanthrotourism in Africa. Annals of Tourism Research 89: 103216 https://doi.org/10.1016/j.annals.2021.103216

Koot, S., R. Hitchcock and C. Gressier. 2019. Belonging, indigeneity, land and nature in Southern Africa under neoliberal capitalism: an overview. Journal of Southern African Studies 45(2): 341-355. https://doi.org/10.1080/03057070.2019.1610243

Lubbe, B., E. du Preez, A. Douglas and F. Fairer-Wessels. 2019. The impact of rhino poaching on tourist experiences and future visitation to National Parks in South Africa. Current Issues in Tourism 22(1): 8-15.

Lunstrum, E. 2014. Green militarization: anti-poaching efforts and the spatial contours of Kruger National Park. Annals of the Association of American Geographers 104(4): 816-832. doi: 10.1080/00045608.2014.912545.

Lunstrum, E. 2016. Feed them to the lions: conservation violence goes online. Geoforum 79: 134-143. http://dx.doi.org/10.1016/j.geoforum.2016.04.009

Lunstrum, E. 2018. Capitalism, wealth, and conservation in the age of security: the vitalization of the state. Annals of the American Association of Geographers 108(4): 1022-1037.

Magole, L. and L. Magole. 2011. Revisiting Botswana's high-value, low-volume tourism. Tourism Analysis 16(2): 203-210.

Malone, S., S. McCabe and A. Smith. 2014. The role of hedonism in ethical tourism. Annals of Tourism Research 44: 241-254.

Marcus, G. 2018. Luxurious emplacement: elite enclosure, as far as the eye can see... Cultural Politics 14(1): 63-77.

Maron, D. 2020. Botswana is evacuating black rhinos amid poaching threat. National Geographic, 1 May.

Massé, F. 2019. Anti-poaching's politics of (in)visibility: representing nature and conservation amidst a poaching crisis. Geoforum 98: 1-14. https://doi.org/10.1016/j.geoforum.2018.09.011

Massé, F. and E. Lunstrum. 2016. Accumulation by securitization: commercial poaching, neoliberal conservation, and the creation of new wildlife frontiers. Geoforum 69: 227-237. doi: https://doi.org/10.1016/j.geoforum.2015.03.005

Mbaiwa, J. 2005. Enclave tourism and its socio-economic impacts in the Okavango Delta, Botswana. Tourism Management 26(2): 157-172.

Mbaria, J. and M. Ogara. 2016. The big conservation lie. Seattle: Lens and Pens Publishers.

McNicoll, A. 2018. The conservation conversation: luxury travel company andBeyond's sustainable philosophy. [accessed 21 August 2018]. https://www.theweek.co.uk/94964/the-conservationconversation-luxury-travel-company-andbeyond-s-sustainable-philosophy.

Morais, D., D. Bunn, G. Hoogendoorn and B. KC. 2018. The potential role of tourism microentrepreneurship in the prevention of rhino poaching. International Development Planning Review 40(4): 443-461. 
Mostafanezhad, M., R. Norum, E. Shelton and A.Thompson-Carr. 2016. Introduction. In Mostafanezhad, M., R. Norum, E. Shelton and A.Thompson-Carr (eds.). Political ecology of tourism: community, power and the environment. London: Routledge.

Ntibinyane, N. 2011. Questionable dealings of connected men. In Mail \& Guardian, 1 July. [accessed 17 August 2021] https://mg.co.za/article/2011-07-01-questionable-dealings-of-connected-men/

Pondoro. 2017. Pondoro Game Lodge: world famous Black Mamba anti-poaching unit tour - R699 per person. [accessed 21 February 2020]. https://pondoro.co.za/blog/world-famous-black-mamba-anti-poachingunit-tour-r699-per-person/.

Raddon, M. 2008. Neoliberal legacies: planned giving and the new philanthropy. Studies in Political Economy 81(1): 27-48. doi: 10.1080/19187033.2008.11675072.

Ramutsindela, M. 2009. The interconnections between environmental philanthropy and business: insights from the Southern African Nature Foundation. Transformation: Critical Perspectives on Southern Africa 70: 54-69.

Ramutsindela, M. 2015. Extractive philanthropy: securing labour and land claim settlements in private nature reserves. Third World Quarterly 36(12): 2259-2272.

Ramutsindela, M., M. Spierenburg and H. Wels. 2011. Sponsoring nature: environmental philanthropy for conservation. London: Routledge.

Reich, R. 2018. Just giving: why philanthropy is failing democracy and how it can do better. Princeton: Princeton University Press.

RM. 2020. The Royal Portfolio: Rhino conservation. [accessed 25 February 2020]. https://www.theroyalportfolio.com/rhino-conservation/.

RR. 2020. Rhino Revolution: What we do. [accessed 21 February 2020]. http://www.rhinorevolution.org/whatwe-do.

RWB. 2016. Rhinos without borders. [accessed 15 September 2016]. http://www.andbeyond.com/conservationcommunity/care-of-the-wildlife/rhinos-without-borders-1.htm.

RWB. 2020. Rhinos Without Borders. [accessed 26 February 2020]. https://www.andbeyond.com/impact/ourimpact-platforms/rhinos-without-borders/.

Saayman, M. and A. Saayman. 2017. Is the rhino worth saving? A sustainable tourism perspective. Journal of Sustainable Tourism 25(2): 251-264.

Salazar, N. 2004. Developmental tourists vs. development tourism: a case study. In Raj, A. (ed.). Tourist behaviour: a psychological perspective. New Delhi: Kanishka Publishers.

Singita. 2018. Conservation up close: an invitation to participate in a critical elephant collaring project. [accessed 21 February 2020]. https://singita.com/conservation-singita/conservation-up-close-aninvitation-to-participate-in-a-critical-elephant-collaring-project/.

Singita. 2020. Safaris with a purpose: participate in a unique conservation experience \& become part of a crucial elephant colouring $\quad$ project. $\quad$ [accessed $21 \quad$ February 2020 ]. http://singita.cmail20.com/t/ViewEmail/r/A09BD6E9F570DE7F2540EF23F30FEDED/CA1219EE3 BAEAFFE6A4D3D471B02C3D7.

Strzelecka, M., G. Nisbett and K. Woosnam. 2017. The hedonic nature of conservation volunteer travel. Tourism Management 63: 417-425.

T\&C. 2015. Rhino Rescue with Uma Thurman, Town \& Country Magazine and Wilderness Safaris. [accessed 19 September 2016]. https://vimeo.com/139361975.

Thakholi, L. 2021. Conservation labour geographies: subsuming regional labour into private conservation spaces in South Africa. Geoforum 123: 1-11.

TIES. 2021. The International Ecotourism Society - What is ecotourism? [accessed 17 March 2021]. https://ecotourism.org/what-is-ecotourism/

Van Beek, W. and A. Schmidt. 2012. African dynamics of cultural tourism. In Van Beek, W. and A. Schmidt (eds.). African hosts \& their guests: cultural dynamics of tourism. Oxford: James Currey. 
Van Dijk, T. 1993. Principles of critical discourse analysis. Discourse \& Society 4(2): 249-283. doi: 10.1177/0957926593004002006.

West, P. and J. Carrier. 2004. Ecotourism and authenticity: getting away from it all? Current Anthropology 45(4): 483-498.

Wilson, J. 2014a. Fantasy machine: philanthrocapitalism as an ideological formation. Third World Quarterly 35(7): 1144-1161. doi: 10.1080/01436597.2014.926102.

Wilson, J. 2014b. The jouissance of philanthrocapitalism: enjoyment as a post-political factor. In Wilson, J. and Swyngedouw, E. (eds.). The post-political and its discontents: spaces of depoliticisation, spectres of radical politics. Edinburgh: Edinburgh University Press.

WS. 2021. Botswana Rhino Reintroduction Project. [accessed 5 May]. https://wildernesssafaris.com/botswana-rhino-reintroduction-project.

WS. 2015. Saving the world, one Black Rhino at a time. [accessed 5 May]. https://wildernesssafaris.com/blog/posts/saving-the-world-one-black-rhino-at-a-time.

WWT. 2016. Wilderness Wildlife Trust: Botswana rhino reintroduction project. [accessed 15 September]. http://www.wildernesstrust.com/portfolio/botswana-rhino-relocation-and-reintroduction/.

Žižek, S. 1989. The sublime object of ideology. London: Verso.

Žižek, S. 2008. For they know not what they do: enjoyment as a political factor. London: Verso. 